\title{
PENGGUNAAN PENDEKATAN CTL UNTUK MENINGKATAN HASIL BELAJAR MATEMATIKA DI KELAS V SD
}

\author{
Faridatul Umi, Taufina
}

Surel: umifaridatul12@gmail.com

\begin{abstract}
ABSTRACK
This study aims to improve mathematics learning outcomes of fifth grade elementary school 05 Air Tawar Barat with a Contextual Teaching And Learning approach. This research is a classroom action research consisting of II cycles with research subjects of fifth grade students The results of the study occurred an increase in each variable in each cycle, where: a) planning the first cycle of 82.14 increased in the second cycle $92.85, b)$ the implementation of aspects of the first cycle teacher 80.35 increased in the second cycle $92.85, c$ ) the implementation of aspects of the first cycle students 71.42 increased in the second cycle $89.28, d$ ) the learning outcomes of the first cycle students 77.70 increased in the second cycle 88.08. The Contextual Teaching And Learning Approach is proven to be able to improve the quality of Mathematics learning in fifth grade SD Negeri 05 Air Tawar Barat.
\end{abstract}

Keywords: CTL, Learning Outcomes, Mathematics

\begin{abstract}
ABSTRAK
Penelitian ini bertujuan untuk meningkatkan hasil belajar Matematika kelas V SDN 05 Air Tawar Barat dengan pendekatan Contextual Teaching And Learning. Penelitian ini adalah penelitian tindakan kelas yang terdiri dari II siklus dengan subjek penelitian siswa kelas V SD. Hasil penelitian terjadi peningkatan dalam setiap variabel dalam setiap siklusnya, dimana : a) perencanaan siklus I sebesar 82,14 meningkat pada siklus II 92,85 , b) pelaksanaan aspek guru siklus I 80,35 meningkat pada siklus II 92,85, c) pelaksanaan aspek siswa siklus I 71,42 meningkat pada siklus II 89,28, d) hasil belajar siswa siklus I 77,70 meningkat pada siklus II 88,08. Pendekatan Contextual Teaching And Learning terbukti meningkatkan hasil pembelajaran Matematika kelas V SDN 05 Air Tawar Barat.
\end{abstract}

Kata kunci: $C T L$, Hasil Belajar, Matematika

\section{PENDAHULUAN}

Matematika merupakan salah satu ilmu yang perlu dipelajari karena dibutuhkan dan berguna dalam kehidupan sehari-hari. Matematika berfungsi mengembangkan kemampuan menghitung, mengukur, dan memecahkan masalah. Seseorang akan merasa mudah memecahkan masalah dengan bantuan matematika, karena matematika itu sendiri memberikan kebenaran berdasarkan alasan logis dan sistematis. Hal ini sesuai dengan Depdiknas (2006:416) yang menyatakan bahwa "Mata pelajaran matematika perlu diberikan mulai dari pendidikan dasar agar peserta didik memiliki kemampuan berpikir logis, analitis, sistematis, kritis, dan kreatif, serta kemampuan bekerjasama". Matematika adalah ilmu dasar yang penting bagi siswa, begitu pentingnya matematika dalam 
kehidupan maka diharapkan semua pihak yang terkait baik dari siswa sendiri, orang tua, guru dan pemerintah dapat melakukan usaha untuk meningkatkan pemahaman yang baik terhadap matematika. Dengan pemahaman yang baik, maka akan mudah mengaplikasikan dalam kehidupan nyata.

Akan tetapi, kenyataan di lapangan belum sesuai dengan tujuan pembelajaran Matematika yang diharapkan. Pada saat peneliti melakukan obeservasi lapangan di kelas V SD Negeri 05 Air Tawar Barat, ditemukannya berbagai maslah yaitu: (1) RPP yang digunakan belum memuat pendekatan maupun model pembelajaran (2) proses pembelajaran yang dilaksanakan masih terpusat pada guru (teacher centre). (3) pembelajaran tidak dikaitkan denga konteks kehidupan sehari-hari (4) proses pembelajaran menggunakan metode konvensional.

Sebagai akibat dari kondisi yang dikemukakan di atas berdampak pada diri siswa, permasalahan dari aspek siswa yaitu, (1) siswa kurang aktif dalam belajar karena terbiasa menerima penyampaian materi oleh guru, (2) siswa mencatat dan mendengarkan penyampain materi oleh guru tanpa memahami betul materi pembelajaran, (3) siswa tidak terlatih dalam memecahkan masalah (4) siswa mudah lupa dengan materi pembelajaran karena siswa tidak belajar melalui proses menemukan atau melalui masalah yang berkaitan dengan kehidupan nyata siswa, (5) siswa merasa jenuh dan bosan saat belajar. Hal ini disebabkan pembelajaran matematika kurang menarik bagi siswa sehingga hasil pembelajaran kurang maksimal yang berakibat pada rendahnya nilai siswa.

Permasalahan juga didukung penelitian yang dilakukan oleh, Hardi (2019) yaitu strategi yang digunakan guru belum cocok dengan pembelajaran. Strategi yang digunakan belum bisa meningkatkan kemampuan berfikir HOT siswa. Selanjutnya Surya, Yenni Fitra (2017) siswa yang belum berani mengeluarkan pendapat karena sudah terbiasa mendengarkan penjelasan dari guru. Dan menurut Ulu, Mustafa dan Kemal Ozdemir (2018) siswa tidak terampil memecahkan masalah berhitung dalam kehidupan keseharian karena kurang terlatih menyelesaikan masalah non-rutin dan memperkirakan jawaban dan perhitungan. Prmaslahan tersebut harus diatasi dan diperlukan sebuah pendekatan yang tepat salah satunya yaitu Contextual Teaching and Learning (CTL).

Pendekatan CTL yaitu pembelajaran berdasarkan kehidupan nyata (Jumanta, 2014). Pendekatan ini membangun pengetahuan siswa melalui penemuan dari pengalamannya di kehidupan nyata. Pendekatan ini juga memiliki kelebihan sehingga patut untuk diterapkan dalam pembelajaran 
kelebihan pendekatan CTL yakni: (1) proses pembelajaran membuat siswa menjadi aktif, (2) belajar dengan kegiatan berkelompok (3) materi dihubungkan dengan kehidupan nyata. Dengan adanya pendekatan CTL dapat merubah suasana belajar siswa karena guru kreatif dalam menyajikan pembelajaran sehingga siswa akan lebih semangat. Dengan pendekatan CTL pembelajaran akan lebih bermakna karena mudah dipahami sehingga hasil belajar siswa meningkat

\section{METODE PENELITIAN}

Tempat penelitian adalah SD Negeri 05 Air Tawar Baratr pada semester ganjil 2018/2019. Subjek penelitian siswa kelas V SD Negeri 05 Air Tawar Barat sebanyak 34 orang adalah. Penelitian ini adalah PTK dan dilaksanakan dua siklus.

$$
\text { Perangkat pembelajaran }
$$

yang digunakan yaitu: Rencana Pelaksanaan Pembelajaran (RPP), Lembar Kegiatan Siswa (LKS) serta media pembelajaran. Lembar observasi berisi data yang didapat dari pengamatan aktivas pembelajaran. Lembar ini akan disusun sesuai dengan pendekatan CTL yang akan digunakan. Tes ini berupa soal matematika yang diberikan di akhir siklus.

dengan: Observasi menggunakan instrumen lembar aktivitas guru dan siswa dengan langkah dari pendekatan CTL.
Dokumetasi

berupa pengambilan foto dibantu teman sejawat. Ketercapaian siswa terhadap materi pembelajaran dilihat dari hasil yang dilakukan pada akhir siklus.

- Analisis Data Aktifitas Guru dan Siswa

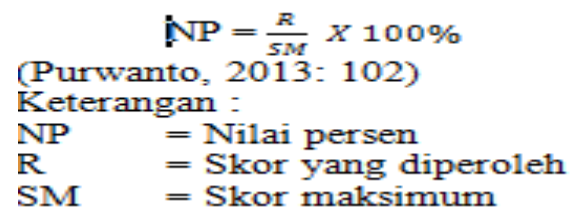

Tabel 3.2 Kategori nilai aktivitas

\begin{tabular}{l|l|}
\hline Interval & Kategori \\
\hline $86-100$ & Sangat Baik \\
\hline $76-85$ & Baik \\
\hline $60-75$ & Cukup \\
\hline $55-59$ & Kurang \\
\hline$<54$ & Kurang Sekali \\
\hline
\end{tabular}

- Analisis Data Hasil Belajar Siswa Rumus nilai hasil belajar:

$$
\begin{aligned}
& \mathrm{S}=\frac{R}{N} \times 100 \\
& \text { (Purwanto, } 2012: 112 \text { ) }
\end{aligned}
$$

Keterangan :

$\mathrm{S}=$ nilai yang diharapkan (dicari)

$\mathrm{R}=$ Jumlah skor dari soal yang benar

$\mathrm{N}=$ Skor maksimum dari tes tersebut.

Rumus menghitung rata-rata :

$$
\mathrm{M}=\frac{2 X}{N}
$$

(Ngalim Purwanto, 2013: 89)

Keterangan :

$\mathrm{M}$ : rata-rata

$\sum \mathrm{x}$ : Jumlah semua skor

$\mathrm{X}$ : Jumlah siswa 
Faridatul Umi, Taufina : Penggunaan Pendekatan ...

\section{HASIL PENELITIAN DAN PEMBAHASAN}

Adapun tahapan penelitian dijelaskan sebagai berikut:

a. Tahap Perencanaan Tindakan. Mempersiapkan perangkat pembelajaran dan instumen pengumpulan data yang diiperlukan dalam menerapkan pendekatan CTL.

b. Tahap Pelaksanaan Tindakan. Pelaksanaan menggunakan pendekatan CTL yang tekag direncanakan.

c. Tahap Pengamatan. Dilakukan oleh seorang pengamat, yaitu guru kelas. Pengamatan dilakukan pada waktu tindakan dengan menggunakan lembar pengamatan terhadap pendekatan CTL yang diterapkan. Lembar pengamatan aktifitas berupa lembar aktifitas siswa.

d. Tahap Refleksi. Tahap refleksi merupakan tahap intropeksi atau tahap dimana peneliti harus mengkaji kembali apa yang telah dilakukan.

Berikut hasil pengamatan RPP dengan pendekatan CTL :

Tabel 4.3 Hasil Pengamatan RPP

\begin{tabular}{|l|l|l|l|l|}
\hline \multirow{2}{*}{ No. } & Tahapan & \multicolumn{2}{c|}{ Peningkatan } & Rata- \\
\cline { 2 - 3 } & & Pert 1 & Pert 2 & rata \\
\hline 1 & Siklus I & $78,57 \%$ & $85,71 \%$ & 82,14 \\
\hline 2 & Siklus II & $92,85 \%$ & $92,85 \%$ & $92,85 \%$ \\
\hline
\end{tabular}

Berikut hasil pengamatan aspek guru dengan pendekatan CTL:
Tabel 4.4 Pengamatan Aspek Guru

\begin{tabular}{|l|l|l|l|c}
\hline No. & Tahapan & \multicolumn{2}{c|}{ Peningkatan } & Rata- \\
\cline { 3 - 4 } & & Pert 1 & Pert 2 & rata \\
\hline 1 & Siklus I & $75 \%$ & $85,71 \%$ & 80,35 \\
\hline 2 & Siklus II & $92,85 \%$ & $92,85 \%$ & $92,85 \%$ \\
\hline
\end{tabular}

Berikut hasil pengamatan aspek siswa dengan pendekatan CTL:

Tabel 4.4 Pengamatan Aspek Siswa

\begin{tabular}{|c|l|l|l|l|}
\hline No. & Tahapan & \multicolumn{2}{c|}{ Peningkatan } & Rata- \\
\cline { 3 - 4 } & & Pert 1 & Pert 2 & \multicolumn{1}{c|}{ rata } \\
\hline 1 & Siklus I & $64,28 \%$ & $78,57 \%$ & 71,42 \\
\hline 2 & Siklus II & $89,28 \%$ & $89,28 \%$ & $89,28 \%$ \\
\hline
\end{tabular}

Berikut hasil belajar belajar siswa dengan pendekatan CTL :

Tabel 4.5 Hasil Belajar Siswa

\begin{tabular}{|c|c|c|c|c}
\hline No. & Tahapan & \multicolumn{2}{c|}{ Peningkatan } & Rata- \\
\cline { 2 - 4 } & & Pert 1 & Pert 2 & rata \\
\cline { 2 - 4 } 1 & Siklus I & $73,95 \%$ & $80,04 \%$ & 77,00 \\
\hline 2 & Siklus II & $88,08 \%$ & $88,08 \%$ & 88,08 \\
\hline
\end{tabular}

Tabel menunjukkan bahwa hasil belajar Matematika siswa mengalami peningkatan setelah penggunaan pendekatan CTL.

\section{Pembahasan}

Penelitian ini menunjukkan bahwa hasil belajar matematika siswa meningkat dengan menggunakan pendekatan CTL. Hasil penelitian dari perencanaan RPP memperoleh rata-rata 82,14 meningkat 92,85. Keberhasilan pelaksanaan aktifitas guru memperoleh rata-rata 80,35 meningkat 92,85. Keberhasilan pelaksanaan aktifitas siswa memperoleh rata-rata 71,42 
meningkat 89,28. Hasil belajar siswa memperoleh rata-rata 77,00 meningkat menjadi 88,08. Berdasarkan uraian hasil penelitian di atas, menunjukkan bahwa pendekatan CTL memiliki pengaruh positif terhadap proses dan hasil belajar.

\section{SIMPULAN}

Berdasarkan hasil penelitian dan analisis data ditarik kesimpulan bahwa penerapan pendekatan CTL dapat meningkatkan hasil belajar matematika siswa kelas V SDN 05 Air Tawar Barat Kota Padang.

$$
\text { Hasil penelitian }
$$

dari perencanaan RPP memperoleh rata-rata 82,14 meningkat menjadi 92,85. Keberhasilan pelaksanaan aktifitas guru memperoleh rata-rata 80,35 meningkat 92,85 keberhasilan pelaksanaan aktifitas siswa memperoleh rata-rata 71,42 meningkat 89,28. Hasil belajar siswa memperoleh rata-rata 77,00 meningkat menjadi 88,08.

\section{DAFTAR RUJUKAN}

Aqib, Z. 2011. Penelitian Tindakan Kelas untuk Guru SMP, SMA, SMK. Bandung: Yrama Wida.

$$
\text { Depdiknas. 2006. Kurikulum }
$$

Tingkat Satuan Pendidikan

Jenjang Pendidikan Dasar.

Jakarta: Depdiknas.

Jumanta Hamdayama. 2014. Model dan Metode

Pembelajaran Kreatif dan Berkarakter. Bogor: Ghalia Indonesia.
Nasikhah, A. 2016. Pengembangan Game Education Pembelajaran Pkn Materi Menghargai Keputsan Bersama Kelas V SD. Jurnal Kreatif. 1(4)

Perwitasari, A. 2014. Peningkatan Kualitas Pembelajaran Pkn Melalui Model Time Token Arends Dengan Media Audio Visual. Joyful Learning Journal. 3(1).

Purwanto, N. 2013. Prinsip-Prinsip dan Teknik Evaluasi Pengajaran. Bandung: Sinar Baru Algesindo.

Surya, Yenni Fitra. 2017. Penerapan Model Pembelajaran Problem Based Learning Untuk Meningkatkan Hasil Belajar Matematika Siswa Kelas IV SDN 016 Langgini Kabupaten Kampar. Jurnal Cendekia: Jurnal Pendidikan Matematika 1 (1): 38-53.

Tambunan, Hardi. 2019. Impact of Heuristic Strategy on Students' Mathematics Ability in High Order Thinking. International Electronic Journal of Mathematics Education. 13(3): 321-328.

Ulu, Mustafa dan Kemal Ozdemir. 2018. Determining the Mental Estimation Strategies Used by Fourth-Grade Elementary Students in Four Basic Mathematical Operations. IEJEE 11(1): 63-75. 